\title{
Three-dimensional preservation of a non-biomineralized arthropod in concretions in Silurian volcaniclastic rocks from Herefordshire, England
}

\author{
PATRICK J. ORR ${ }^{1}$, DEREK E. G. BRIGGS ${ }^{2}$, DAVID J. SIVETER ${ }^{3} \&$ DEREK J. SIVETER ${ }^{4}$ \\ ${ }^{1}$ Department of Earth Sciences, University of Oxford, Parks Road, Oxford OX1 3PR, UK \\ Present address: Department of Geology, National University of Ireland, Galway, Galway, Ireland \\ (e-mail:0005025s@bodkin.nuigalway.ie) \\ ${ }^{2}$ Department of Earth Sciences, University of Bristol, Queen's Road, Bristol BS8 1RJ, UK \\ ${ }^{3}$ Department of Geology, University of Leicester, University Road, Leicester LE1 7RH, UK \\ ${ }^{4}$ Geological Collections, University Museum of Natural History, Oxford OX1 3PW, UK
}

\begin{abstract}
Three-dimensional preservation of a non-biomineralized arthropod occurs in carbonate concretions in a volcaniclastic deposit from the Wenlock Series of Herefordshire, England. Specimens are preserved in calcite that co-precipitated with framboids and polyhedra of pyrite. The texture of the calcite indicates that it is a void infill. It forms a cast of the external surface of the arthropod, having precipitated after decay of even the most recalcitrant biological tissues. Incorporation of the fossils into concretions ensured their long term preservation but was not, at least in most examples, responsible for preventing potential collapse and occlusion of voids in the interval between the decay of tissues and the precipitation of calcite. The precipitation and/or accumulation of clay minerals adjacent to specimens during decay was important in this process, as were possibly the geotechnical properties of the ash itself. Limited dolomitization of the calcite around the edges of the fossils and in the matrix of the concretion occurred at a later stage.
\end{abstract}

Keywords: Silurian, England, arthropods, preservation, concretions.

The arthropod specimens analysed in the present paper come from a recently discovered Konservat Lagerstätte from the Silurian of Herefordshire, England (Briggs et al. 1996). The term Konservat Lagerstätte encompasses those fossil deposits that preserve lightly sclerotized and soft-bodied organisms. Such deposits are rare and of fundamental importance to our knowledge of the history of life on earth.

Konservat Lagerstätten provide a more complete record of the diversity and ecology of ancient communities than does the normal shelly fossil record. Conway Morris (1986) calculated that only about $14 \%$ of genera and $2 \%$ of live individuals in the Middle Cambrian Burgess Shale of British Columbia possessed biomineralized tissues at the time of burial. Often, Konservat Lagerstätten provide the only evidence of many extinct types of organism; for example, Opabinia Walcott 1912 and the possibly related Myoscolex Glaessner 1979 are only known from the Burgess Shale and the Lower Cambrian Emu Bay Shale of South Australia, respectively. Konservat Lagerstätten also provide information to identify taxa otherwise known only from isolated biomineralized elements. The affinities of conodont elements were uncertain until the associated soft tissues were discovered in the Granton 'shrimp bed' (Lower Oil Shale Group; Dinantian, Carboniferous), near Edinburgh, Scotland (Briggs et al. 1983; Aldridge et al. 1993). In addition, the palaeobiological information provided by Konservat Lagerstätten can be used to incorporate otherwiseunknown morphologies into phylogenetic reconstructions of the major metazoan groups (e.g. Wills et al. 1994; Wills 1998).

Despite the wealth of palaeobiological information that Konservat Lagerstätten provide, they, too, are subject to preservational biases. A full understanding of the taphonomy of any exceptionally preserved fauna is essential to ensure that the evidence it provides is correctly interpreted. Nonbiomineralized tissues display a range of susceptibility to decay (taphonomic thresholds: Allison \& Briggs 1991). An important control on this process is the composition of the tissues themselves. For arthropods, a convenient distinction can be made between structural organic tissues (for example, cuticle) and the more labile tissues that comprise musculature and internal organs. A heavily biomineralized exoskeleton is a feature of only a small proportion of arthropods (e.g. some trilobites and crustaceans; millipedes). The extensive fossil record of the arthropods (see Briggs \& Clarkson 1989; Shear \& Kukalova-Peck 1990) reflects the resistance of the organic cuticle to decay, especially when tanned or sclerotized, and its tendency to alter to a stable biopolymer during diagenesis (Stankiewicz et al. 1997).

The biology and chemistry of the early diagenetic environment are important for the preservation of non-biomineralized tissues. Paradoxically, the majority of specimens of Myoscolex from the Emu Bay Shale preserve only phosphatized musculature (some of the most labile tissues); a tiny minority also retain evidence of the more recalcitrant, organic, cuticle. Recognition of the importance of bacterially-mediated processes in the fossilization of certain tissues allowed the interpretation of Myoscolex not as a polychaete (Glaessner 1979), but as an arthropod (Briggs \& Nedin 1997).

Taxon-related controls on mineralization have been demonstrated (Wilby \& Whyte 1995). The microfabric of phosphatized soft tissues varies in arthropods, cephalopods and fish, reflecting the relative resistance of their tissues to invasion by microbes during decay (Wilby \& Briggs 1997). Thus the taphonomy of individual taxa in any exceptionally preserved fauna may not be common to the biota as a whole. 

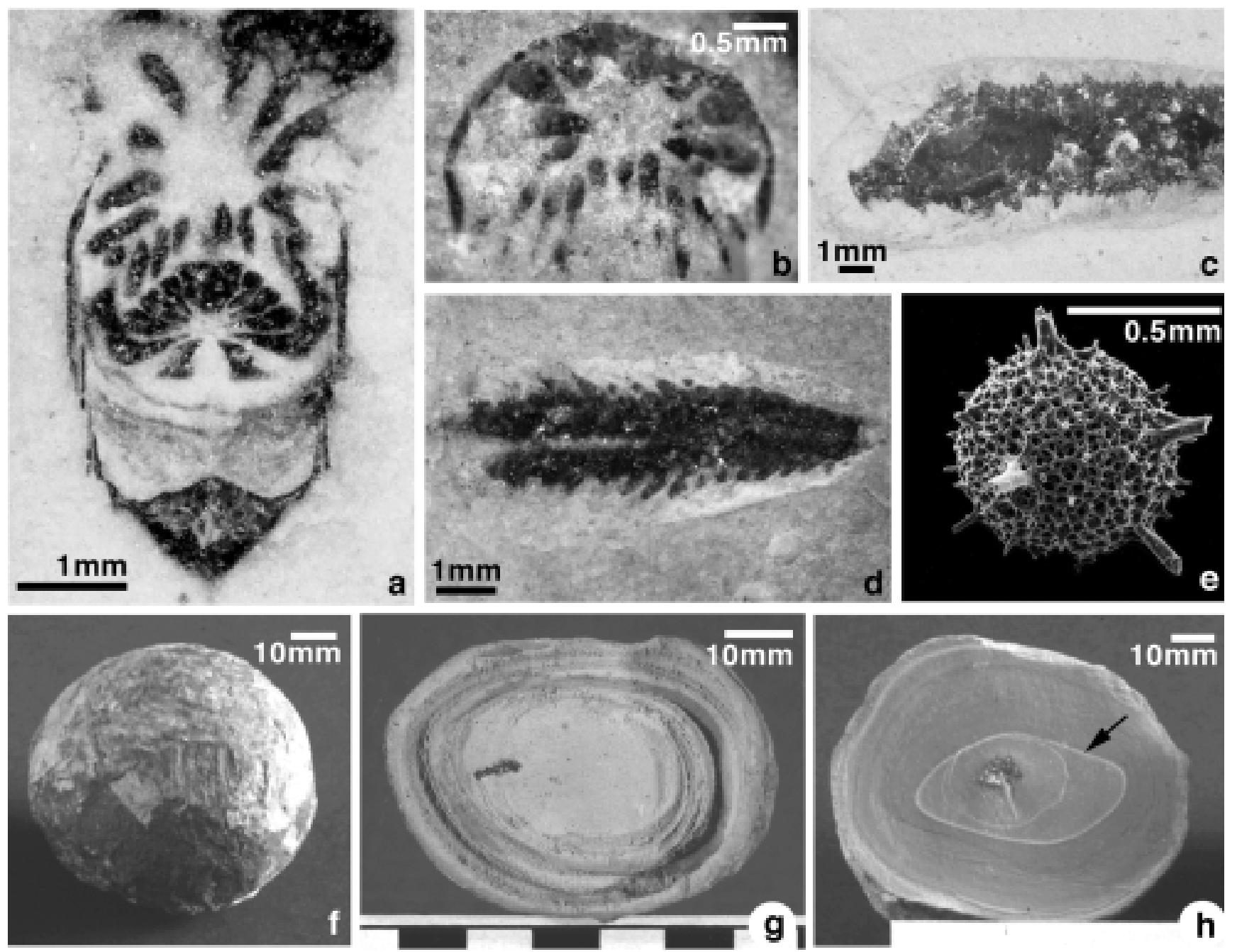

Fig. 1. Representative unnamed taxa (a-e) from the Herefordshire concretions (f-h). (a, b) Horizontal section (a) and transverse section (b) through as yet unnamed arthropod (a: OUM C.29509a; b: OUM C. 29510a). (c, d) Two species of polychaete worms (c: OUM C. 29503a; d: OUM C. 29511a). (e) Radiolarian (OUM C. 29502). (f) Entire concretion. (g) Entirely weathered concretion with three-dimensional polychaete towards periphery (OUM C.29512). (h) Concretion with unweathered core (OUM C.29513a).

Preservation of non-biomineralized tissues within concretions occurs through most of the Phanerozoic, from the Upper Cambrian (Alum Shale, Sweden: Müller 1985; Walossek \& Müller 1992) to the Recent (Champlain Sea, Ottawa, Canada: McAllister et al. 1988; Holman et al. 1997). Examples occur in a variety of different environmental settings, including lacustrine (Barstow Formation, Middle Miocene, USA: Palmer 1957; Park 1995), fluvio-deltaic ('Mazon Creek-type' biotas: Baird et al. 1985; Schram et al. 1997), lagoonal/shallow marine (Santana Formation, lower Cretaceous, Brazil: Martill 1997) and deeper marine (La Voulte-sur-Rhône biota, Middle Jurassic, France: Wilby et al. 1996).

\section{The Herefordshire biota}

This paper discusses the taphonomy of a new arthropod (Fig. 1a, b), which is the most common faunal element within the Herefordshire biota, of lower Silurian, Wenlock age (430 $424 \mathrm{Ma})$. The arthropod occurs in association with a diverse macrofauna that includes polychaete worms (Fig. 1c, d), sponges, graptolites and other, as yet unnamed or unidentified taxa. A diverse microfauna/microflora includes abundant, well-preserved radiolarians (Fig. 1e). The fossils are preserved in three dimensions (cf. Fig. 1a, b) within carbonate concretions (Fig. 1f-h).

The concretions occur within a fine-grained volcaniclastic ash that punctuates a sequence of carbonate muds that accumulated in an outer shelfal environment (Briggs et al. 1996). The ash is local in occurrence; its maximum thickness is about $1 \mathrm{~m}$, but it thins laterally to a few tens of centimetres over about $40 \mathrm{~m}$. This variation in thickness reflects, at least in part, undulations in the topography of the sea floor at the time of deposition. The ash is highly weathered and it is uncertain whether it represents one event, or several, closely spaced events.

Individual concretions are two to $20 \mathrm{~cm}$ in diameter; most are spherical or sub-spherical in outline (Fig. 1f). The majority occur isolated within the volcanic ash; a few occur as coalesced concretions. Where the volcanic ash is at its thickest, the concretions appear to be more numerous in the uppermost $20-30 \mathrm{~cm}$ of the deposit. Most of the concretions have been weathered concentrically but remain hard (Fig. 1g); a minority 


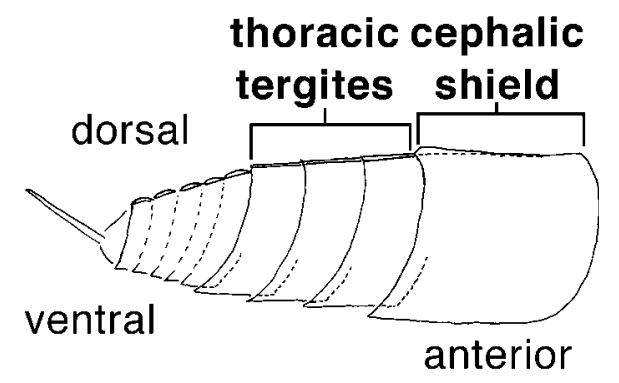

Fig. 2. Simplified reconstruction of the unnamed arthropod showing the morphological features referred to in the text.

retain an unweathered, blue to grey coloured core (at arrow in Fig. 1h). Only specimens that occur within the unweathered core were analysed.

\section{Relationship between the fossils and the concretions}

There is no correspondence between the size and/or shape of a concretion and the fossil(s) it contains, in contrast to examples from elsewhere (e.g. the Mazon Creek and Santana biotas); more than one specimen usually occurs in a concretion and their position may not be central. The preserved fossils rarely represent loci around which the concretions have precipitated, although there may have been an organic nucleus. The nonbiomineralized organisms identified to date (the arthropod that is the subject of the present paper, polychaete worms and graptolites) are characterized by having possessed relatively recalcitrant tissues. Other organisms, e.g. sponges, are represented by articulated skeletal remains, but no evidence of more labile tissues is preserved. Organisms composed exclusively of more labile tissues may have been sites of concretion nucleation, but decayed without leaving a trace. The three-dimensional preservation clearly required exceptional conditions.

\section{Materials and methods}

Standard, polished, uncovered thin-sections were examined using a Nikon binocular microscope with Technosyn Cold Cathode Luminescence equipment (Model 8200MkII). Photographs were taken using a Nikon camera with auto-exposure facility (Figs 3, 5a-f).

Thin sections were carbon-coated prior to electron microprobe analysis. Elemental mapping (Figs $5 \mathrm{~g}$, h, 6) was performed on a Jeol JXA8600 Superprobe (Department of Earth Sciences, University of Bristol): operating voltage $15 \mathrm{kV}$; 32 milliseconds dwell time; beam current $15 \mathrm{nAmps}$; beam diameter variable in relation to size of area being mapped; all elements energy dispersive (Oxford Instruments AN10000). Spot analyses of the composition of minerals (Table 1) were made using this electron microprobe. Fully quantitative analyses were difficult to obtain for the clay minerals; they do not polish well and tend to pluck from the surface of the slide during preparation (e.g. see Fig. 7f). The exceptions are the small kaolinites with angular outlines that tend to occur within and adjacent to the arthropod (at arrow in Fig. 4d). Sequential spot analyses (at $10 \mu \mathrm{m}$ increments) across specimen OUM C.29505 along the line indicated in Fig. $4 \mathrm{~b}$ were made using a Cambridge Instruments Microscan 9 electron microprobe (Department of Earth Sciences, University of Oxford); the results are plotted in Fig. 11. Back-scattered electron images of carbon-coated thin sections (Figs 4 \& 7-10) were generated on a Cambridge Stereoscan S250Mk3 scanning electron microscope (operating voltage $15 \mathrm{kV}$ ) (Department of Earth Sciences, University of Bristol).
Specimens used for this study are housed in the Oxford University Museum of Natural History (numbers OUM C.29505-C.29508). Anatomical and descriptive terms referred to in the text are explained in Fig. 2.

\section{Analytical Results \\ Petrology of the fossils}

Most of the arthropods consist of an infill of sparry calcite with uniform luminescence (e.g. Fig. 3a, 5a). The size of individual crystals increases towards the interior of each specimen (Fig. 3a), but the composition of the calcite does not vary systematically (points indicated in Fig. 7a; data in Table 1).

In specimens OUM C.29505 and OUM C.29506 there is a narrow $(0-200 \mu \mathrm{m}$ wide), continuous fringe of fibrous calcite around the periphery (Figs 3c, 5c); individual crystals are small, wedge-shaped and oriented normal to the margin of the specimen, with their apexes directed medially. Similar fibrous calcite occurs on the ventral side of specimen OUM C.29507 (Figs 3f, 5f). Where present, this fibrous calcite comprises most or all of the infill of smaller volumes: for example, in the thoracic appendages in specimens OUM C.29507 and OUM C. 29506 (Fig. 3c, f; at arrow in Mn map in Fig. 6c). Cathodoluminescence colour and brightness vary between, but are uniform within, the fibrous calcite and the sparry calcite. This corresponds to subtle chemical differences between the two. In specimen OUM C.29505, the fibrous calcite is the more brightly luminescent as $\mathrm{Mn}$ is more abundant, but the amount of $\mathrm{Fe}$ in both is negligible (see Fig. 11). Conversely, in specimen OUM C.29506 the fibrous calcite is more weakly luminescent than the sparry calcite (Fig. 5b, c), despite having elevated levels of Mn (Mn map in Fig. 6c). Levels of Fe (the principal ion responsible for quenching cathodoluminescence) are not obviously different between the fibrous and sparry calcite in the corresponding elemental map (Fe map in Fig. 6c). However, spot analyses of individual crystals (Fig. 8b: data in Table 1) show, on the whole, a higher Fe content in the fibrous than in the sparry, calcite. Spot analyses of individual crystals show no significant variations in the composition of the sparry calcite (Fig. 8b, c; data in Table 1).

Both the fibrous and sparry calcite are associated spatially with scattered framboids (10-20 $\mu \mathrm{m}$ diameter) and numerous small polyhedra (c. $2 \mu \mathrm{m}$ diameter) of pyrite (Figs $4 \mathrm{c}, 7 \mathrm{~h}, 8 \mathrm{c}$ ). The pyrite tends to be restricted to the marginal parts of the larger volumes of calcite (e.g. Fig. 7g, h) but occurs throughout smaller areas (e.g. the thoracic tergites in specimen OUM C.29506; Fig. 8c). The pyrite polyhedra are concentrated along the junction between crystals of calcite (Figs $7 \mathrm{~g}, 9 \mathrm{c}$, d). Small areas of kaolinite also occur within the margin of the calcite; the outlines of these areas are markedly angular in thin section (at arrows in Figs 4d, 7i). There is a more extensive development of clay (illite and kaolinite), quartz, and ferroan dolomite rhombs between the inner surface of the dorsal tergites and the ventral exoskeleton of specimen OUM C.29506 (Fig. 8a, c). The ferroan dolomite rhombs are concentrated along the inner surface of the tergites and along a line connecting the bases of the thoracic appendages; this is well displayed in the elemental maps for $\mathrm{Fe}$ and $\mathrm{Mg}$ in Fig. 6b. Individual rhombs are crudely zoned with a more ferroan core (Fig. 7c; data in Table 1). The intervening area is dominantly a mixture of clay and quartz. These same minerals, with the same textures, form the fringe that occurs immediately adjacent to specimens (see Petrology of the concretion matrix, below). 
Table 1. Results of electron microprobe spot analyses; see figures cited for location of analyses in, and details of, each specimen

\begin{tabular}{|c|c|c|c|c|c|c|c|c|c|c|}
\hline & $\mathrm{Na}_{2} \mathrm{O}$ & $\mathrm{MgO}$ & $\mathrm{SiO}_{2}$ & $\mathrm{Al}_{2} \mathrm{O}_{3}$ & $\mathrm{~K}_{2} \mathrm{O}$ & $\mathrm{CaO}$ & $\mathrm{TiO}_{2}$ & $\mathrm{FeO}$ & $\mathrm{MnO}$ & Total \\
\hline \multicolumn{11}{|c|}{ Figure $7 a$} \\
\hline 1 & - & 0.06 & - & - & 0.01 & 54.74 & - & - & 1.14 & 55.88 \\
\hline 2 & 0.03 & 0.22 & 0.61 & 0.55 & 0.03 & 54.16 & 0.06 & 0.36 & 0.53 & 56.44 \\
\hline 3 & 0.06 & - & 0.11 & - & 0.01 & 55.04 & - & 0.08 & 0.94 & 56.08 \\
\hline 4 & - & - & 0.01 & 0.02 & - & 54.06 & - & 0.18 & 0.57 & 54.80 \\
\hline 5 & - & 0.02 & - & - & 0.01 & 55.32 & - & 0.10 & 0.69 & 56.01 \\
\hline 6 & - & 0.04 & 0.02 & - & 0.04 & 55.40 & - & 0.18 & 0.83 & 56.45 \\
\hline 7 & 0.01 & - & - & 0.01 & - & 54.07 & - & 0.15 & 0.86 & 54.93 \\
\hline 8 & 0.04 & 0.06 & - & - & - & 54.23 & - & 0.07 & 0.66 & 54.90 \\
\hline 9 & - & 0.11 & 0.11 & 0.04 & 0.05 & 54.84 & 0.07 & 0.21 & 0.83 & 56.04 \\
\hline 10 & 0.11 & 0.03 & - & - & - & 53.00 & - & - & 1.15 & 54.15 \\
\hline 11 & 0.10 & 0.05 & 0.02 & - & 0.02 & 53.64 & - & 0.15 & 0.77 & 54.41 \\
\hline 12 & - & 0.09 & 0.03 & 0.02 & - & 55.18 & - & 0.07 & 0.82 & 56.00 \\
\hline 13 & - & - & - & 0.05 & - & 54.60 & - & 0.20 & 1.00 & 55.86 \\
\hline 14 & 0.08 & - & - & - & 0.02 & 54.75 & - & 0.19 & 0.79 & 55.73 \\
\hline 15 & - & 0.11 & - & - & 0.02 & 54.88 & - & 0.06 & 1.01 & 56.00 \\
\hline 16 & 0.04 & 0.06 & 0.01 & - & - & 54.62 & - & 0.11 & 0.95 & 55.58 \\
\hline 17 & - & 0.01 & 0.01 & - & 0.02 & 53.49 & - & - & 0.97 & 54.46 \\
\hline 18 & - & 0.07 & 0.05 & - & - & 55.73 & - & - & 0.60 & 56.33 \\
\hline 19 & 0.05 & - & - & - & - & 54.97 & - & - & 0.76 & 55.73 \\
\hline 20 & 0.08 & 0.06 & 0.01 & - & 0.01 & 53.57 & - & 0.13 & 0.81 & 54.39 \\
\hline \multicolumn{11}{|c|}{ Figure $7 c$} \\
\hline 1 & 0.12 & 13.06 & 2.43 & 0.95 & 0.15 & 29.17 & 0.19 & 8.43 & 0.04 & 54.38 \\
\hline 2 & - & 11.99 & 0.94 & 0.56 & 0.07 & 3.06 & 0.01 & 40.83 & 0.17 & 57.45 \\
\hline 3 & 0.03 & 14.10 & 1.71 & 1.23 & 0.18 & 29.78 & 0.01 & 8.91 & 0.11 & 55.91 \\
\hline 4 & 0.04 & 0.13 & 0.41 & 0.26 & 0.02 & 57.99 & 0.02 & 1.03 & 2.18 & 61.99 \\
\hline 5 & 0.03 & 13.73 & 1.48 & 1.01 & 0.13 & 30.65 & 0.20 & 8.71 & 0.08 & 55.90 \\
\hline 6 & 0.17 & 12.38 & 0.72 & 0.53 & 0.05 & 3.79 & 0.02 & 40.16 & 0.28 & 58.07 \\
\hline 7 & 0.03 & 11.62 & 2.95 & 0.44 & 0.09 & 30.66 & 0.09 & 10.95 & 0.25 & 57.07 \\
\hline 8 & - & 13.94 & 1.03 & 0.72 & 0.08 & 31.55 & - & 8.72 & 0.03 & 56.03 \\
\hline 9 & - & 0.13 & 2.00 & 0.59 & 0.10 & 51.28 & 0.85 & 0.62 & 1.33 & 56.91 \\
\hline \multicolumn{11}{|c|}{ Figure $7 e$} \\
\hline 1 & 0.26 & 0.01 & 1.46 & 1.13 & 0.12 & 0.64 & - & 59.28 & 0.04 & 62.89 \\
\hline 2 & 0.21 & 0.22 & 1.33 & 0.99 & 0.13 & 12.28 & - & 47.22 & 0.16 & 62.15 \\
\hline 3 & - & 12.64 & 1.04 & 0.56 & 0.06 & 3.32 & 0.12 & 40.60 & 0.10 & 58.34 \\
\hline 4 & - & 10.10 & 2.90 & 2.21 & 0.02 & 32.17 & 0.03 & 9.68 & 0.26 & 57.32 \\
\hline 5 & 0.06 & 0.29 & 1.63 & 0.80 & 0.07 & 55.33 & - & 1.01 & 0.55 & 59.68 \\
\hline 6 & - & 11.93 & 1.01 & 0.44 & 0.07 & 29.79 & 0.10 & 11.35 & 0.14 & 54.70 \\
\hline 7 & - & 0.17 & 0.16 & 0.06 & 0.01 & 56.82 & - & 0.51 & 1.50 & 59.24 \\
\hline 8 & 0.04 & 13.74 & 2.07 & 1.68 & 0.15 & 28.79 & 0.02 & 8.65 & 0.12 & 55.07 \\
\hline 9 & 0.02 & 0.05 & 44.55 & 39.52 & 0.02 & 0.52 & - & 0.25 & - & 84.84 \\
\hline \multicolumn{11}{|c|}{ Figure $7 i$} \\
\hline 1 & 0.05 & 10.06 & 4.68 & 3.22 & 0.36 & 1.82 & - & 39.79 & 0.29 & 60.22 \\
\hline 2 & 0.11 & 12.39 & 3.37 & 2.82 & 0.25 & 28.67 & 0.36 & 9.59 & 0.08 & 57.44 \\
\hline 3 & - & 11.66 & 1.13 & 0.54 & 0.07 & 29.76 & 0.03 & 10.65 & 0.31 & 54.13 \\
\hline 4 & 0.11 & 13.30 & 1.72 & 1.14 & 0.09 & 29.44 & - & 10.19 & 0.10 & 55.88 \\
\hline 5 & - & 12.13 & 0.70 & 0.39 & 0.04 & 3.90 & 0.10 & 37.22 & 0.26 & 54.74 \\
\hline 6 & - & - & 38.63 & 33.78 & - & 6.67 & 0.04 & 0.12 & 0.12 & 79.08 \\
\hline 7 & - & 0.02 & 45.51 & 39.37 & 0.02 & 0.62 & 0.01 & 0.22 & - & 85.72 \\
\hline 8 & 0.11 & 0.54 & 45.69 & 36.60 & 1.92 & 0.70 & 0.29 & 0.84 & 0.06 & 86.58 \\
\hline 9 & 0.22 & 1.00 & 47.81 & 34.66 & 4.09 & 0.62 & - & 0.96 & - & 89.35 \\
\hline \multicolumn{11}{|c|}{ Figure $8 b$} \\
\hline 1 & - & 0.15 & 0.02 & - & 0.05 & 55.58 & 0.03 & 0.28 & 1.12 & 57.18 \\
\hline 2 & 0.03 & 0.05 & 0.06 & - & - & 58.09 & - & 0.03 & 0.82 & 58.91 \\
\hline 3 & 0.02 & - & 0.01 & 0.04 & - & 55.41 & - & 0.31 & 1.22 & 56.93 \\
\hline 4 & - & 0.02 & - & - & - & 55.96 & - & 0.47 & 1.33 & 57.76 \\
\hline 5 & 0.01 & - & - & - & - & 55.75 & 0.02 & 0.07 & 0.90 & 56.65 \\
\hline 6 & - & - & 0.04 & - & - & 55.54 & - & 0.30 & 1.06 & 56.90 \\
\hline 7 & 0.04 & - & 0.01 & 0.03 & 0.02 & 55.99 & - & 0.30 & 0.94 & 57.23 \\
\hline 8 & - & 0.01 & - & - & 0.04 & 55.79 & - & 0.84 & 1.37 & 58.04 \\
\hline 9 & 0.03 & - & - & - & 0.01 & 55.38 & - & 0.35 & 1.31 & 57.04 \\
\hline 10 & 0.07 & 0.05 & 0.07 & - & - & 55.91 & 0.02 & 0.63 & 1.38 & 57.98 \\
\hline 11 & 0.01 & - & - & 0.03 & 0.01 & 55.19 & - & 0.34 & 1.11 & 56.64 \\
\hline 12 & - & - & - & - & - & 56.09 & - & - & 0.75 & 56.84 \\
\hline
\end{tabular}


Table 1. Continued

\begin{tabular}{|c|c|c|c|c|c|c|c|c|c|c|}
\hline & $\mathrm{Na}_{2} \mathrm{O}$ & $\mathrm{MgO}$ & $\mathrm{SiO}_{2}$ & $\mathrm{Al}_{2} \mathrm{O}_{3}$ & $\mathrm{~K}_{2} \mathrm{O}$ & $\mathrm{CaO}$ & $\mathrm{TiO}_{2}$ & $\mathrm{FeO}$ & $\mathrm{MnO}$ & Total \\
\hline \multicolumn{11}{|c|}{ Figure $8 b$ continued } \\
\hline 13 & 0.03 & 0.07 & - & - & - & 56.51 & - & 0.11 & 0.75 & 57.26 \\
\hline 14 & 0.03 & 0.08 & - & - & - & 55.95 & - & 0.09 & 0.60 & 56.55 \\
\hline 15 & - & 0.10 & 0.01 & - & - & 56.05 & 0.03 & 0.31 & 0.61 & 57.08 \\
\hline 16 & 0.02 & 0.04 & - & 0.05 & - & 55.96 & - & - & 0.55 & 56.51 \\
\hline 17 & - & 0.03 & 0.02 & - & - & 55.10 & - & 0.13 & 0.73 & 55.83 \\
\hline 18 & - & 0.01 & - & - & 0.01 & 55.54 & 0.06 & 0.23 & 0.86 & 56.63 \\
\hline 19 & - & - & 0.02 & - & 0.01 & 56.12 & - & 0.31 & 0.76 & 57.19 \\
\hline \multicolumn{11}{|c|}{ Figure $8 c$} \\
\hline 1 & - & 0.02 & 0.01 & - & 0.01 & 56.73 & - & 0.08 & 0.96 & 57.69 \\
\hline 2 & - & 0.02 & - & - & - & 56.52 & - & - & 0.79 & 57.31 \\
\hline 3 & - & 0.03 & 0.05 & 0.01 & - & 55.65 & - & 0.10 & 1.09 & 56.74 \\
\hline 4 & - & 0.08 & - & 0.02 & - & 56.46 & - & - & 1.17 & 57.63 \\
\hline 5 & 0.07 & 0.01 & - & 0.03 & 0.02 & 55.79 & - & 0.12 & 0.69 & 56.48 \\
\hline 6 & 0.01 & - & 0.01 & - & 0.01 & 56.84 & - & 0.11 & 0.87 & 57.71 \\
\hline 7 & - & 0.02 & - & - & - & 55.84 & - & - & 0.35 & 56.19 \\
\hline 8 & 0.01 & - & 0.01 & - & - & 55.84 & - & 0.12 & 0.85 & 56.69 \\
\hline 9 & - & - & 0.01 & 0.01 & 0.01 & 55.69 & - & 0.14 & 1.13 & 56.82 \\
\hline 10 & 0.05 & - & - & - & - & 56.34 & - & 0.27 & 1.11 & 57.72 \\
\hline \multicolumn{11}{|c|}{ Figure $9 d$} \\
\hline 1 & - & 0.02 & 0.03 & - & - & 55.03 & 0.03 & 0.58 & 1.12 & 56.74 \\
\hline 2 & 0.02 & 0.06 & 0.02 & - & - & 55.05 & - & 0.01 & 0.70 & 55.74 \\
\hline 3 & - & 0.12 & 0.01 & - & - & 55.80 & 0.01 & 0.35 & 1.40 & 57.66 \\
\hline 4 & - & - & - & 0.02 & 0.03 & 56.19 & - & - & 0.86 & 57.05 \\
\hline 5 & 0.08 & 0.06 & 0.01 & - & 0.01 & 54.43 & 0.06 & - & 0.76 & 55.20 \\
\hline 6 & - & - & - & - & - & 55.90 & 0.01 & 0.19 & 0.87 & 56.96 \\
\hline 7 & 0.01 & 0.03 & 0.01 & 0.01 & 0.02 & 55.85 & 0.02 & 0.02 & 0.72 & 56.57 \\
\hline 8 & 0.02 & - & - & - & 0.03 & 57.25 & - & 0.07 & 0.79 & 58.07 \\
\hline 9 & 0.01 & 0.09 & - & 0.02 & - & 56.56 & - & - & 0.72 & 57.29 \\
\hline \multicolumn{11}{|c|}{ Figure $9 e$} \\
\hline 1 & 0.05 & - & 0.07 & - & - & 55.00 & - & 0.16 & 0.76 & 55.83 \\
\hline 2 & - & 0.03 & 0.06 & 0.01 & 0.01 & 53.97 & - & 0.41 & 1.14 & 55.52 \\
\hline 3 & - & 0.02 & 0.01 & - & - & 55.64 & - & 0.18 & 0.50 & 56.32 \\
\hline 4 & - & - & - & - & 0.02 & 56.11 & - & 0.12 & 0.93 & 57.04 \\
\hline 5 & 0.07 & 0.06 & 0.03 & 0.02 & - & 54.93 & 0.06 & 0.28 & 1.02 & 56.23 \\
\hline 6 & 0.14 & 0.05 & - & - & - & 55.34 & - & 0.54 & 1.34 & 57.36 \\
\hline 7 & - & 0.02 & 0.03 & - & - & 56.26 & - & 0.17 & 1.10 & 57.53 \\
\hline 8 & 0.02 & 0.09 & 0.05 & 0.01 & - & 54.75 & - & 0.32 & 1.50 & 56.56 \\
\hline 9 & 0.07 & - & - & - & - & 56.63 & - & 0.05 & 0.50 & 57.13 \\
\hline 10 & - & - & - & - & - & 56.31 & - & 0.17 & 0.66 & 57.14 \\
\hline 11 & - & 0.02 & 0.01 & - & - & 56.66 & - & 0.08 & 0.40 & 57.06 \\
\hline 12 & - & 0.01 & - & - & - & 54.91 & - & 0.18 & 0.74 & 55.65 \\
\hline 13 & - & - & - & 0.02 & - & 56.97 & - & - & 0.88 & 57.85 \\
\hline 14 & 0.01 & - & - & - & - & 55.52 & - & 0.27 & 0.74 & 56.53 \\
\hline 15 & 0.04 & 0.10 & 0.05 & - & - & 55.28 & - & 0.01 & 1.09 & 56.47 \\
\hline 16 & - & - & - & - & - & 55.60 & - & 0.06 & 0.58 & 56.18 \\
\hline 17 & - & - & 0.04 & - & - & 56.50 & - & 0.07 & 0.50 & 57.00 \\
\hline 18 & - & - & - & - & - & 55.30 & - & - & 0.64 & 55.94 \\
\hline 19 & - & 0.06 & - & 0.01 & - & 57.79 & - & - & 0.60 & 58.39 \\
\hline 20 & 0.04 & - & 0.02 & - & - & 55.67 & - & 0.05 & 0.30 & 55.97 \\
\hline
\end{tabular}

Small (c. $1 \mu \mathrm{m}$ diameter) crystals of calcium phosphate are aligned in a narrow, anterio-posteriorly oriented band in the posterior of specimen OUM C.29506 (Fig. 6c; map for P). They are insufficiently numerous to define any structure, but their distribution and position suggests that they may represent the site of the gut.

\section{Petrology of the concretion matrix}

A localized (Figs 8a, 9a) or continuous (Fig. 4a) fringe of clay (illite and kaolinite), quartz and rhombs of ferroan dolomite surrounds the specimens. The interlocking, euhedral, rhombs of dolomite have an idiotopic-e texture (sensu Gregg \& Sibley 1984: a planar-e texture sensu Sibley \& Gregg 1987). They are crudely zoned with a more ferroan core; in some the core is ankerite (Fig. 7c, e, i; data in Table 1). The dolomite rhombs project orthogonally away from the margin of the calcite that infills the arthropod (Figs 4d, 7b). They also occur at the periphery of the fringe in association with the calcite of the concretion matrix (Fig. 7c, g) and more rarely within the fringe, which is dominantly clay (illite and kaolinite) and quartz. This distribution is evident in the sequential spot analyses along line A-B in specimen OUM C.29505 (Figs 4b, 11). Levels of iron and magnesium are elevated at the inner 

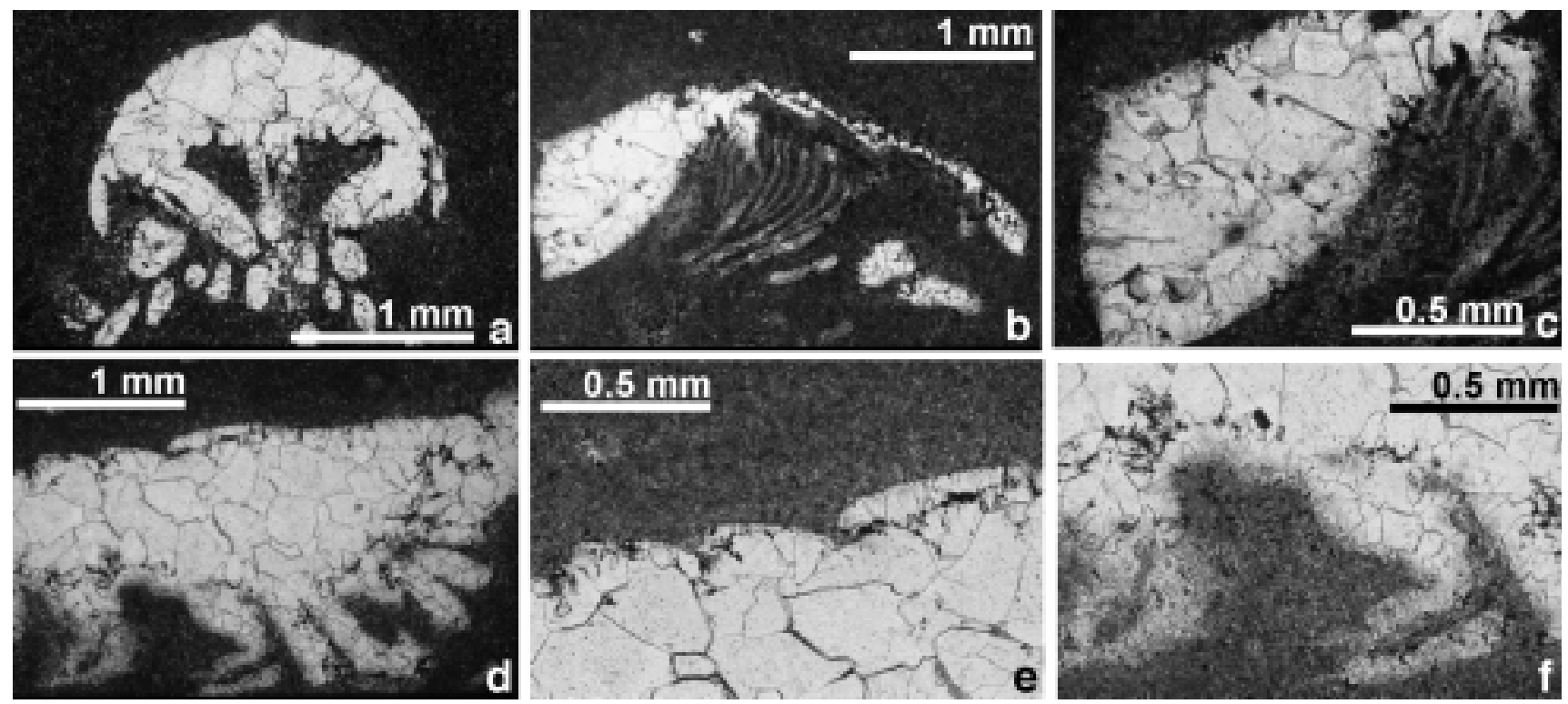

Fig. 3. Thin-section photomicrographs (PPL) of specimens of the unnamed arthropod. (a) Transverse section (OUM C.29508). (b, c) Longitudinal sections (OUM C.29506). (d-f) Longitudinal sections (OUM C.29507).

and outer margins of the fringe around the specimen, while levels of aluminium, potassium and silicon are elevated medially. Framboids and polyhedra of pyrite, the polyhedra in linear trains as inside the arthropod (see above), occur between and possibly within the dolomite rhombs (at arrows in Fig. 4f).

The thickness of the fringe is highly variable. In specimen OUM C.29506 the fringe is thickest adjacent to the dorsal tergites but thins anteriorly and posteriorly; the same minerals also occur inside specimen OUM C.29506 in the same location, but are absent elsewhere (Fig. 8a). In specimen OUM C.29508, the fringe is thickest medio-dorsally, and thins rapidly laterally; there are also thick developments of the fringe vertically below this on the ventral side of the animal within the confines of the cephalic shield (Fig. 7a). It is possible that these variations in the thickness of the fringe are geopetal fabrics, although the 'way-up' of the specimens at the time of burial is not known.

The concretion matrix is dominantly an interlocking mosaic of calcite, ferroan dolomite and quartz (Fig. 10). The dolomite shows the same composition and textures as that in the fringe adjacent to fossils. Boundaries between patches of calcite and ferroan dolomite are poorly defined. The dolomite crystals project into areas of clay (illite and kaolinite) and quartz that infill angular interstices within the framework of the carbonate minerals (at shorter arrow in Fig. 10b). Irregularly shaped patches of ankerite occur within areas of calcite (at longer arrow in Fig. 10b). Pyrite is absent from the matrix.

Over short distances $(c .0 .5 \mathrm{~mm})$ from the fossils the matrix shows no systematic variation in the concentration $\left(\mathrm{wt}^{\mathrm{\%}} \%\right)$ of the eight most abundant elements (Figs 6b, 11). Over larger distances, the matrix surrounding the fossil is depleted in calcium while levels of aluminium, iron, magnesium and silicon are elevated relative to the matrix as a whole (specimens OUM C.29508 and OUM C.29506: Figs 5g, 6a). Specimen OUM C.29507 displays a more complex pattern (Fig. 5h). As in the other specimens, the matrix surrounding the fossil is depleted in calcium, and levels of aluminium, iron, magnesium and silicon are elevated, relative to the matrix as a whole. This halo, however, is surrounded by a second in which silicon and particularly aluminium are depleted, and magnesium slightly elevated, relative to the matrix as a whole; this second halo is not expressed in the elemental maps for calcium and iron.

\section{Internal or external mould?}

The biomineralized shells of trilobites, gastropods and brachiopods are preserved within the concretions. In contrast, the tergites of the arthropod show no evidence of an originally biomineralized cuticle; they are preserved in sparry calcite that lacks internal structure (Fig. 8c).

In specimen OUM C.29506 both the internal and external surfaces of the thoracic tergites are evident (Fig. 8c); elsewhere in this specimen, and in the others examined, the arthropod is preserved as a calcite cast that replicates the outline of only one surface of the exoskeleton (e.g. Fig. 4a). The first cement (i.e. the fibrous calcite in some specimens; the smaller crystals of sparry calcite in others) precipitated at the periphery. Whether the calcite fill precipitated before or after the cuticle decayed determined whether the result is a cast of an internal or external mould.

In horizontal sections the cephalic shield and individual thoracic tergites of the arthropod can be identified (Fig. 1a). Vertical sections through the anterior show the outline of the arch-like cephalic shield (Fig. 1b). In each case a discrete thickness that corresponds to the original cuticle is preserved. The calcite has infilled voids created by the decay of the exoskeleton of the arthropod.

Experiments have shown that in decaying arthropods internal voids are created as a result of the greater recalcitrance of the exoskeleton than the musculature and internal organs (Briggs \& Kear 1994, fig. 1d: Stage 3: hollow). The cuticle subsequently becomes flaccid and can collapse under its own weight (Briggs \& Kear 1994). These experiments emphasize that there is a brief temporal window between the creation of internal voids by decay and their occlusion by collapse. Precipitation of calcite during this time would form an internal cast of the organism. A second phase of calcite precipitation after decay of the cuticle would preserve its external outline. 

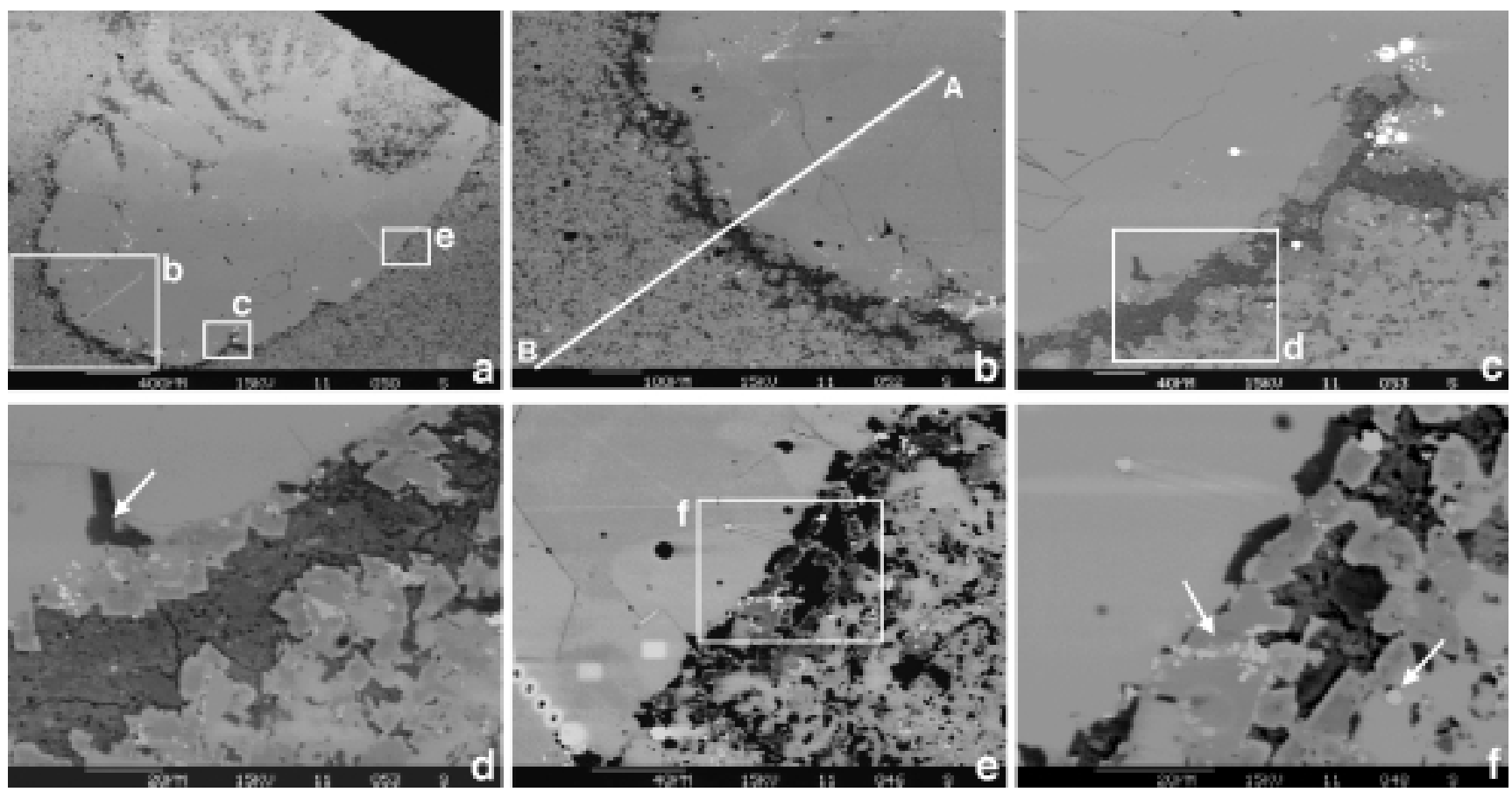

Fig. 4. Backscattered electron micrographs of an oblique longitudinal section of the unnamed arthropod (OUM C.29505). For areas outlined in (a) (c) and (e) see (b, c, e), (d) and (f), respectively. A-B in (b) represents line along which composition was determined by electron microprobe spot analyses at $10 \mu \mathrm{m}$ intervals; results are plotted in Fig. 11.

There is no evidence, however, that the calcite precipitated in two phases. In specimen OUM C.29507 the posterior margin of the cephalic shield overlaps the anterior margin of the first thoracic tergite (Fig. 9d); the succeeding thoracic tergites show the same overlapping arrangement (Fig. 9e). The overlapping parts of each are separated by a thin layer of identical composition to that of the fringe. As a result both the inner and outer surfaces of the cuticle can be identified (e.g. the cephalic shield in Fig. 9d; the first thoracic tergite in Fig. 9e). There are no systematic variations in cathodoluminescence (Fig. 5d) nor in the composition of the calcite that defines the cuticle and that within the body of this specimen (Fig. 9d, e; data in Table 1). Clearly, the void was infilled in a single phase after decay of the cuticle. None of the original tissues of the arthropod have been replicated during fossilization.

Any taphonomic model therefore must include a mechanism by which voids are retained, possibly under load from the surrounding matrix, after the tissues have decayed.

\section{Relative timing of mineral formation}

The sparry calcite is interpreted as a single phase of precipitation that infilled external moulds of the arthropod. In some specimens, however, it was preceded by an earlier phase of fibrous calcite that incompletely filled the voids.

The inclusion of pyrite framboids in crystals of calcite (e.g. Fig. 4c) suggests that the two precipitated contemporaneously. The small pyrite polyhedra dominantly occur along the boundary between adjacent calcite crystals (e.g. Figs $7 \mathrm{~g}, 9 \mathrm{c}$ ). Calcite can be inhibited from precipitating on surfaces on which pyrite has previously developed (Wilby et al. 1996). Thus the pyrite polyhedra presumably formed on the surfaces of calcite crystals during short hiatuses in the precipitation of calcite in the void. The pyrite was then enclosed by calcite growing from the other direction.
The same elements that comprise the minerals within the fringe around the fossils show elevated levels in the matrix beyond (Figs 5g, h, 6a). Thus the organism clearly influenced the spatial distribution of elements, as a result of interaction between clay minerals (either new precipitates, or particulates in pore water) and the products of the initial stages of decay of the arthropod; clay minerals are known to have an affinity for organic matter (Mortland 1970; Odom 1984; Lagaly 1984; Jackson et al. 1978; Williams \& Cusack 1997). Authigenic mineralization must have occurred at a very early stage. This notion is supported by the localised occurrence of kaolinite within the fossils and precipitation of the minerals of the fringe within specimen OUM C.29506 (Fig. 8c).

The association of ferroan dolomite rhombs and clay is evident not only adjacent to the fossils but also in the matrix of the concretion, most notably where the clay fills the interstices within the interlocking mosaic of calcite crystals (at shorter arrow in Fig. 10b). The indistinct boundaries between these dolomite rhombs and the calcite suggests that the latter has been partially dolomitized. Irregular patches of ankerite also occur within the calcite (at longer arrow in Fig. 10b). The margins of the fossil also appear to have been dolomitized. The ferroan dolomite rhombs in the fringe are concentrated adjacent to the calcite of the fossil (Fig. 4d); some of them have ankerite cores (Fig. 7c, i; data in Table 1). In places pyrite framboids and polyhedra occur associated with the ferroan dolomite rhombs, the latter aligned as they would have been within the original calcite (compare Figs 4f, 9c). Thus dolomitization postdated precipitation of the calcite in both the fossils and the concretion. The formation of the ferroan dolomite may have been initiated by release of suitable ions during conversion of smectite to illite during diagenesis (as suggested by McHargue \& Price 1982); this idea is supported by the spatial association with clay minerals. 

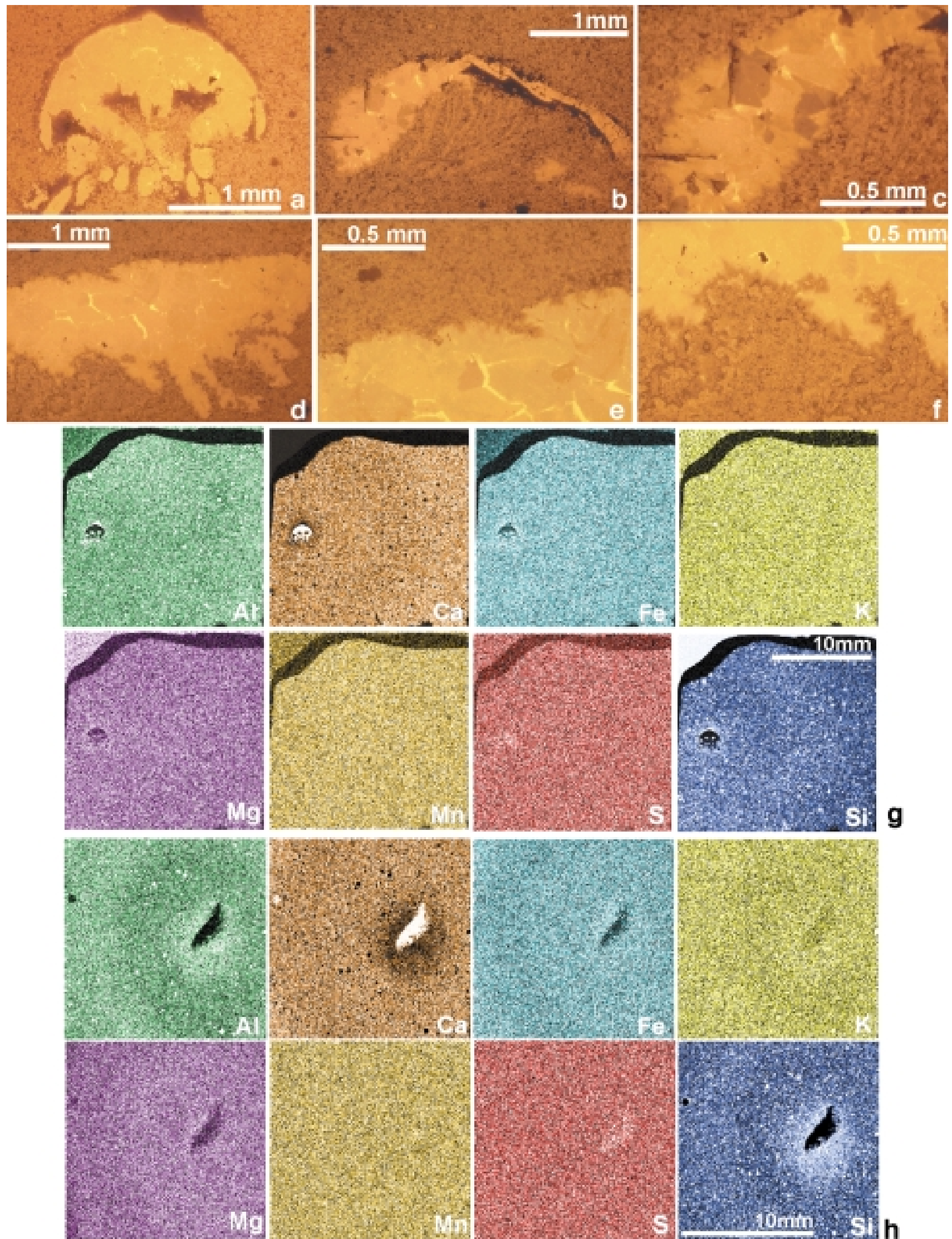

Fig. 5. Cathodoluminescence images (a-f) and elemental maps ( $g, h)$ of specimens of the unnamed arthropod. (a, g) Transverse sections (OUM C.29508). (b, c) Longitudinal sections (OUM C.29506; see also Fig. 6). (d-f, h) Longitudinal sections (OUM C.29507). 

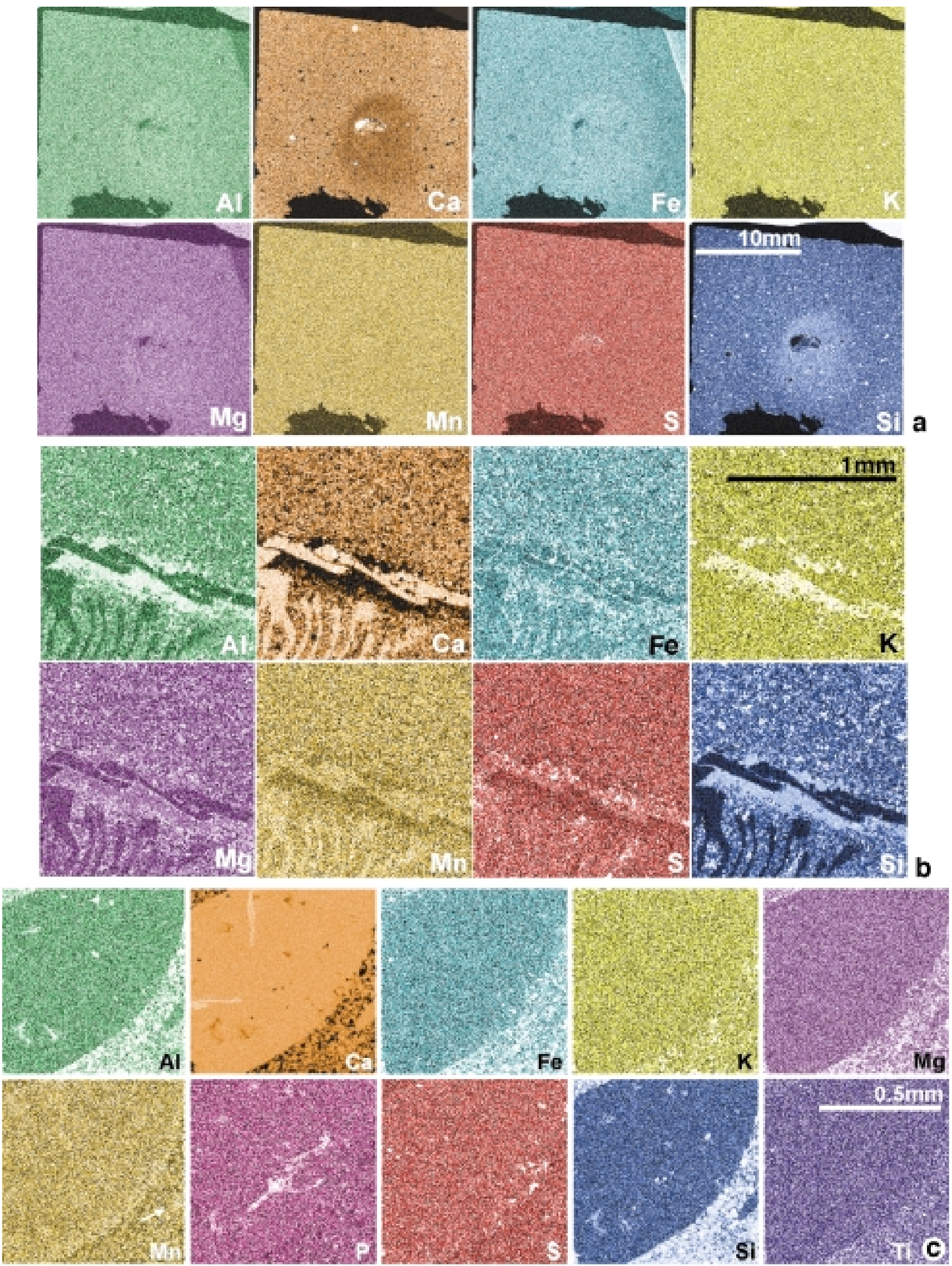

Fig. 6. Elemental maps of the unnamed arthropod (OUM C.29506). (a) complete specimen. (b) mid-dorsal region showing thoracic tergites and appendages. (c) posterior region 

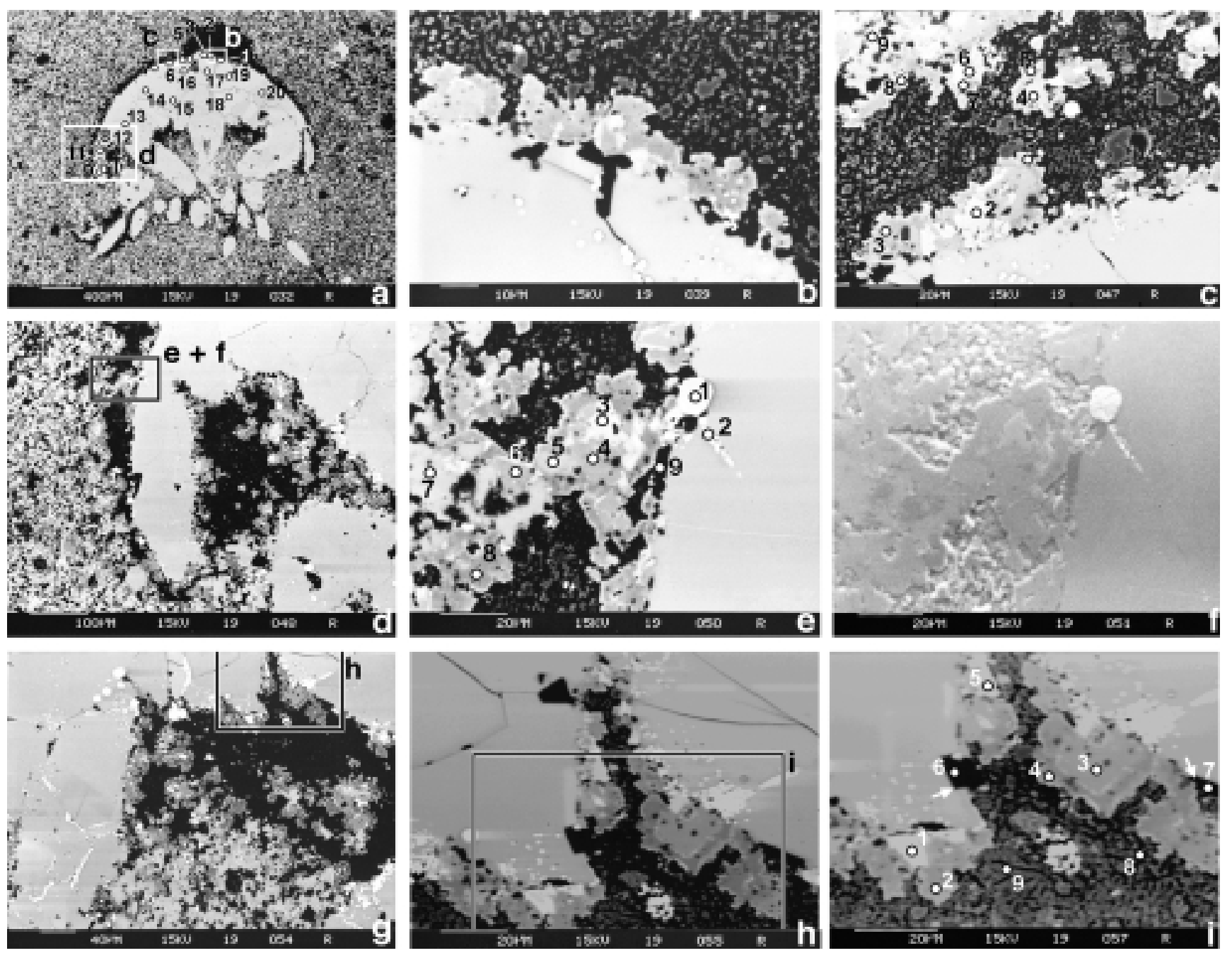

Fig. 7. Backscattered electron micrographs (a-e, g-i) and secondary electron micrograph (f) of a transverse section of the unnamed arthropod (OUM C.29508). For areas outlined in (a), (d), (g) and (h) see (b, c, d), (e, f), (h) and (i), respectively. Compositions determined by electron microprobe spot analyses at points indicated in (a) (c) (e) and (i); see data in Table 1.
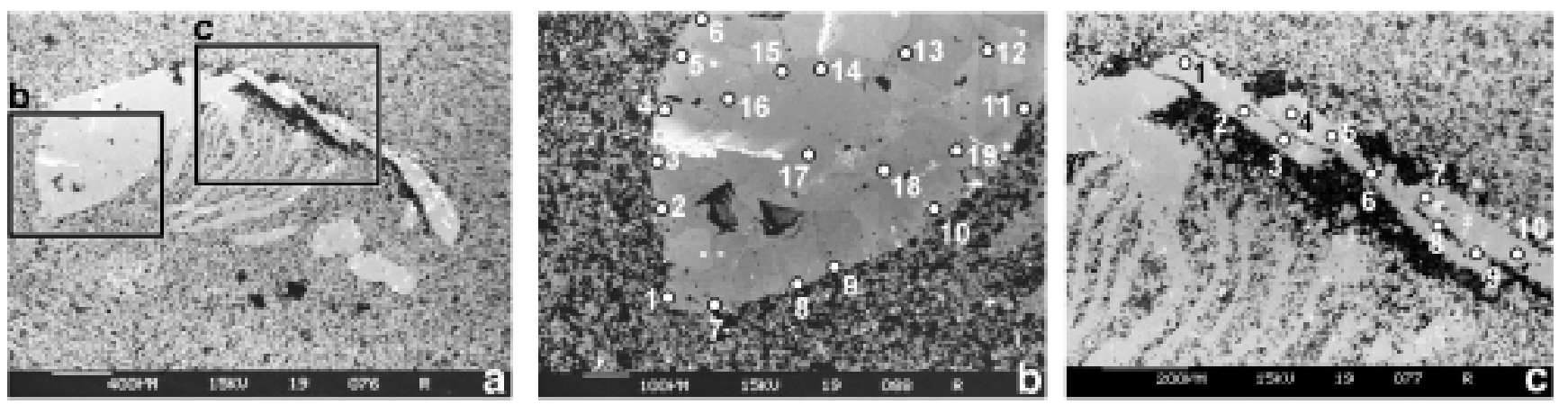

Fig. 8. Backscattered electron micrographs of a longitudinal section of the unnamed arthropod (OUM C.29506). For areas outlined in (a) see (b) and (c). Compositions determined by electron microprobe spot analyses at points indicated in (b) and (c); see data in Table 1.

\section{A taphonomic model}

The preservation of the arthropod involved the following steps (Fig. 12).

\section{Entombment}

The biota was entombed in fine-grained volcanic ash (Fig. 12a). Ash surrounded the specimen and pervasively infiltrated spaces within the arthropod, for example between 

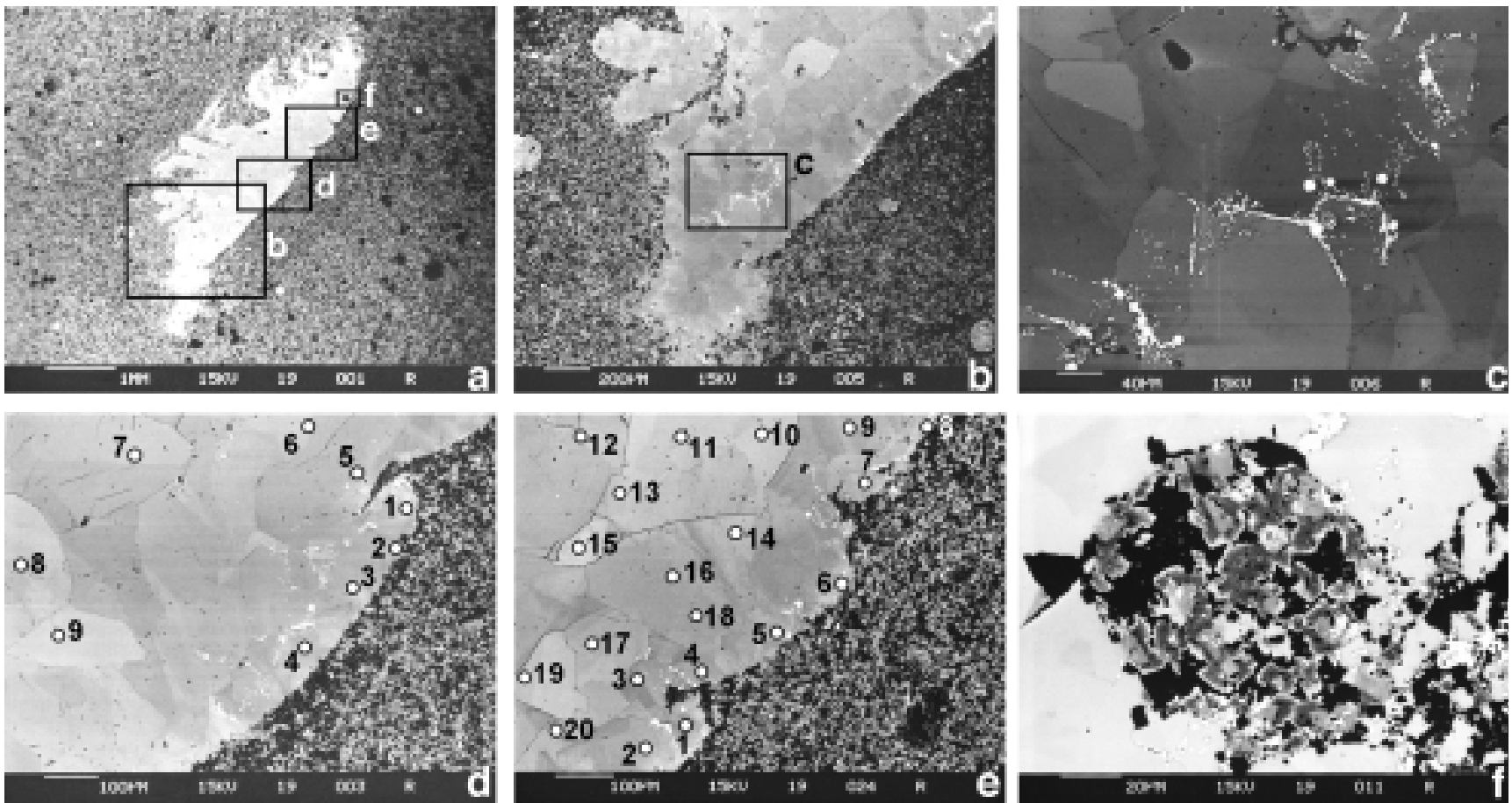

Fig. 9. Backscattered electron micrographs of a longitudinal section of the unnamed arthropod (OUM C.29507). For areas outlined in (a) and (b) see (b, d-f) and (c), respectively. Compositions determined by electron microprobe spot analyses at points indicated in (d) and (e); see data in Table 1 .

the appendages and between the overlapping tergites (Fig. 1a). An example of the arthropod preserved at the termination of an (unsuccessful) escape trace (specimen OUM C.29514a, b), indicates that at least some of the organisms were alive at time of burial.

\section{Decay and formation of external mould}

Decay products leaked from the specimen into the adjacent matrix. As a result, chemical gradients were established and clay minerals (at least kaolinite: the illite may be the result of later diagenetic alteration, see below) accumulated, either as new precipitates or existing particulates, in the pore spaces adjacent to and more rarely within specimens (specimen OUM C.29506: Fig. 8c) (Fig. 12b). Internal voids resulted from the more rapid decay of internal organs and musculature than the cuticle of the exoskeleton.

Calcium phosphate precipitated locally; in the posterior of specimen OUM C.29506 small crystals are aligned along a narrow, anteriorly-directed, band presumed to be the trace of the gut. The precipitation of calcium phosphate was probably biologically mediated (e.g. Wilby \& Briggs 1997) and may have occurred preferentially within the gut because of the presence of indigeneous micro-organisms.

The precipitation of both kaolinite and calcium phosphate is favoured by acidic porewaters. Experimental studies of arthropods have shown that the $\mathrm{pH}$ of the surrounding water usually falls during the initial stages of decay (Briggs \& Kear 1994, fig. 5).

Progressive decay of the rest of the arthropod, including the external cuticle resulted in the formation of an external mould of the animal in the volcanic ash (Fig. 12c).
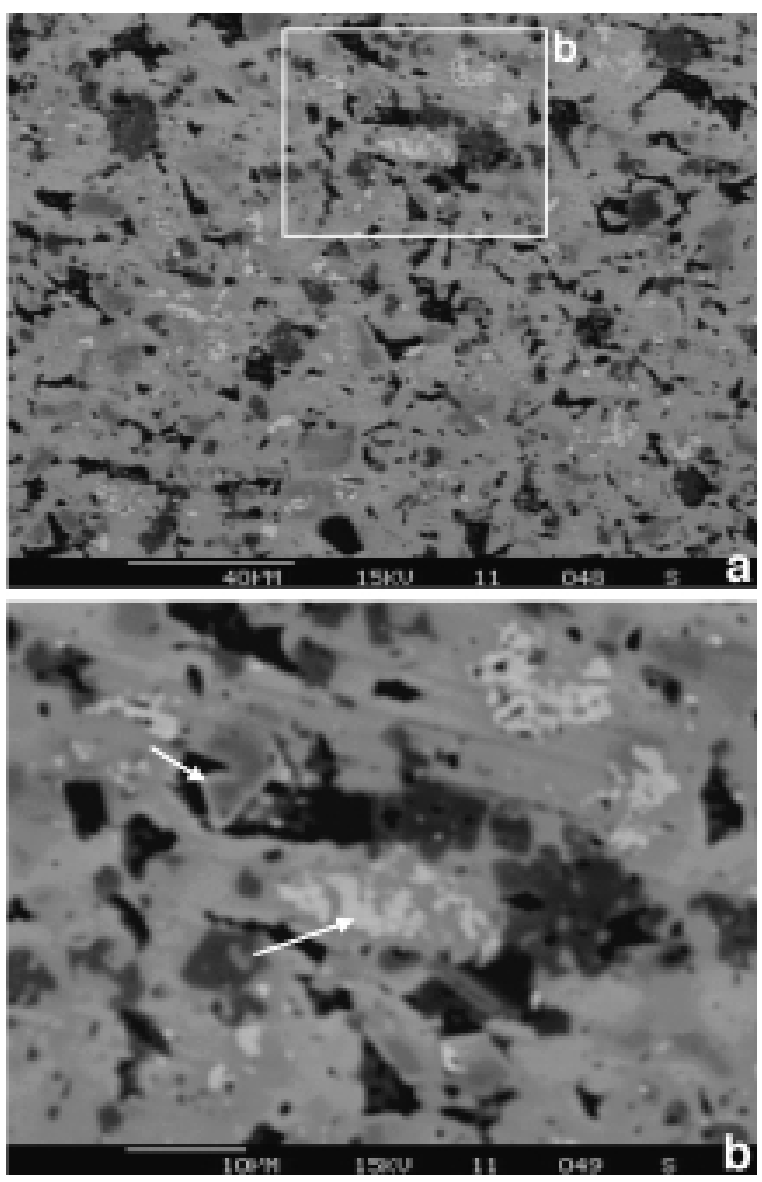

Fig. 10. Backscattered electron micrographs of matrix of concretion in specimen OUM C.29505. For area outlined in (a) see (b). 

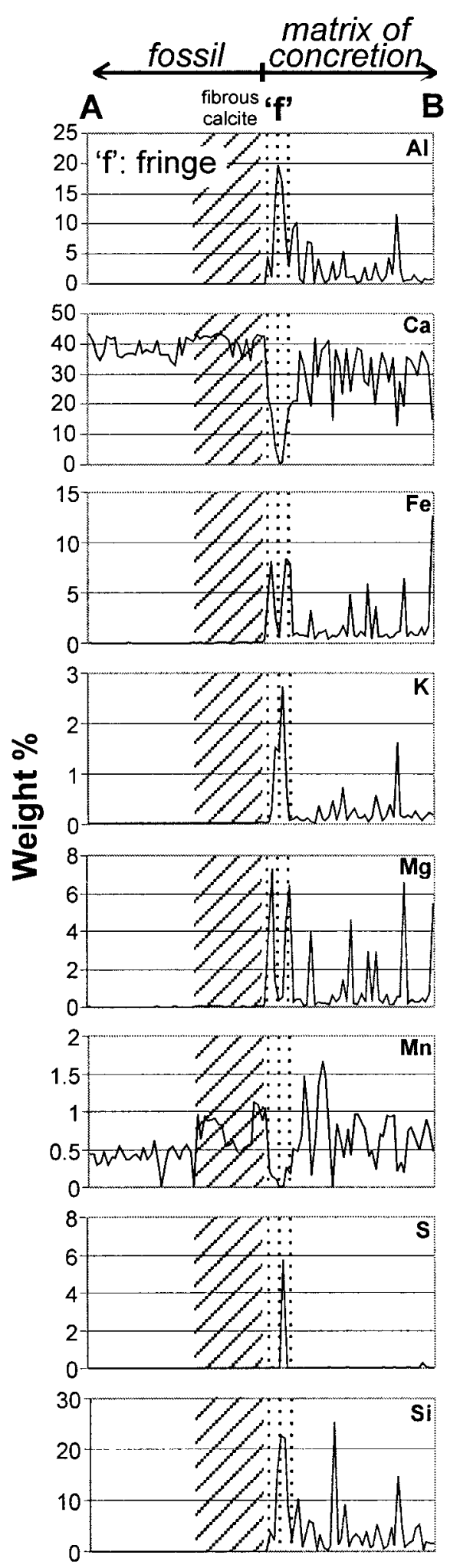

Fig. 11. Plots of the abundance (weight \%) of the most abundant elements along the line A-B indicated in Fig. $4 \mathrm{~b}$.

\section{Retention of voids}

Following decay the voids remained open until they were infilled by minerals.
Experiments have demonstrated that regardless of starting conditions, the carcasses of polychaetes are reduced to two dimensions within 8 days at $20^{\circ} \mathrm{C}$ (Briggs \& Kear 1993). Unless growth of the concretions was extremely rapid (on order of tens of $\mathrm{cm}$ in a few days) the incorporation of organisms into the concretion cannot be invoked to explain their preservation in three dimensions. As exceptionally preserved threedimensional fossils occur both in the peripheral parts of the concretions (Fig. 1g) and at their centres (Fig. 1h), this is the case whether each concretion grew from a central nucleus outwards, or, as has been documented in certain examples, from the periphery inwards (Coleman 1993).

The non-biomineralized taxa preserved in three dimensions are characterized by an external cuticle. The decay resistance of this cuticle may have provided a longer temporal window for other processes to operate. Potential contributing factors include the following.

(a) Precipitation, or accumulation, of clay minerals in the pore spaces surrounding specimens would have increased the viscosity and strength of the ash, as well as forming a mould of the external surface of the arthropod.

(b) Arthropods and polychaetes swell during the initial stages of decay as a result of the uptake of fluids and the production of decay gases (Briggs \& Kear 1993, 1994). If confined by the surrounding sediment this would result in an increase in turgor. Collapse of the specimen as a result of the loss of structural strength of the cuticle may therefore have been delayed, or retarded.

(c) Upon settling many fine-grained lithologies exhibit thixotropic behaviour. This might have prevented collapse of the matrix into voids created by decay. Allison (1988) buried freshly killed carcasses of the polychaete Nereis in jars containing sediment and water from marine, brackish or lacustrine environments. The jars were sampled at intervals between 2 and 25 weeks. No remains of Nereis were recovered but perfect moulds of the carcasses were occasionally encountered when frozen jars of sediment were broken open for analysis. The extent to which these moulds were three-dimensional was not recorded, but the sediment may have been sufficiently cohesive to retain the shape of a worm carcass that subsequently collapsed and decayed (Briggs \& Kear 1993).

\section{Infill of voids}

Precipitation of calcite and pyrite in either a single phase of mineralization (sparry calcite alone) or two phases (an initial phase of fibrous calcite around the periphery followed by sparry calcite medially) infilled the voids and preserved the fossils as external casts (Fig. 12d). The calcite is presumably a product of reaction between bicarbonate ions generated by microbial decay and calcium ions (Berner 1968; Irwin et al. 1977; Chaftez \& Buczynski 1992). The depletion of calcium in the vicinity of the arthropod is an obvious source of the calcium ions.

\section{Incorporation into concretions}

The cement of the concretion is dominantly calcite; the calcite forms an interlocking mosaic of crystals, in the interstices of which clay occurs. The incorporation of the fossils into the growing concretions may have been concurrent with the infill of voids by calcite. 

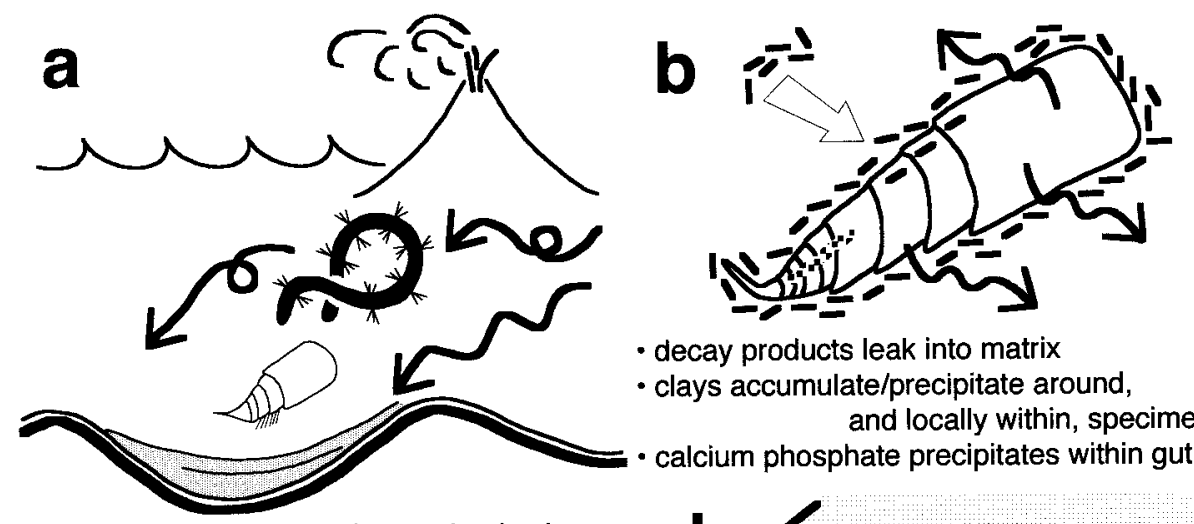

- decay products leak into matrix

- clays accumulate/precipitate around, and locally within, specimens

- entombment of biota in fine-grained ash

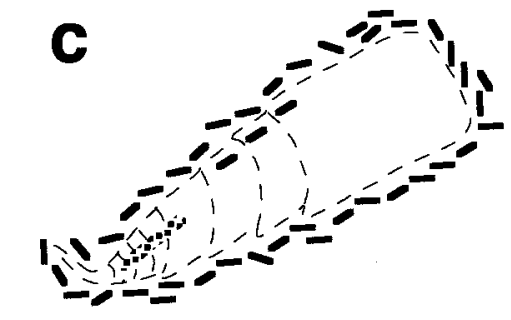

- decay of biological tissue results in external mould

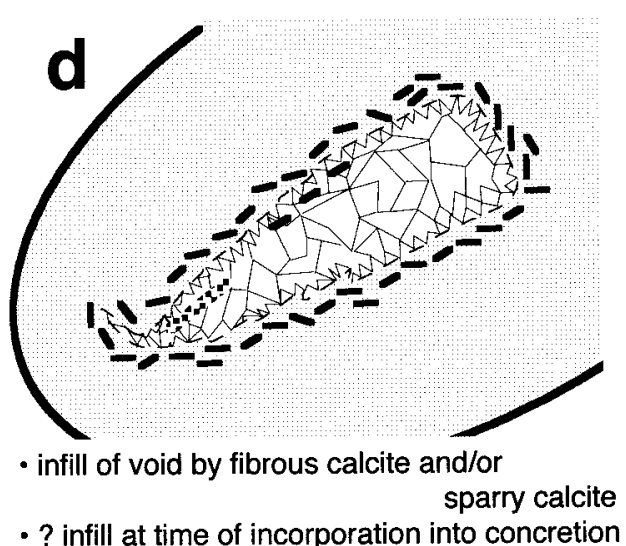

- ? infill at time of incorporation into concretion

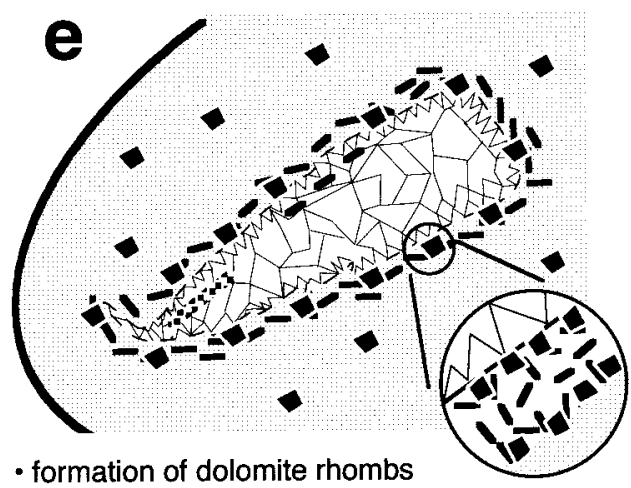

spatially associated with clay and calcite f -N clay minerals

calcium phosphate
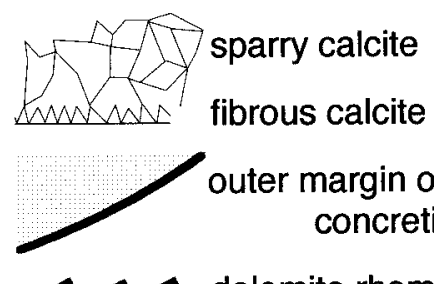

outer margin of concretion

dolomite rhombs
Fig. 12. Model for the taphonomy of the unnamed arthropod within the Herefordshire concretions.

\section{Dolomitization}

Rhombs of ferroan dolomite occur both in the fringe around the fossils and within the matrix of the concretion. The control on their distribution appears to be proximity to both clay and calcite; at least some are a product of localized dolomitization of the calcite itself. Dolomitization therefore postdated calcite precipitation within the fossils and the matrix of the concretion (Fig. 12e). The iron and magnesium of the dolomite were sourced from a precursor clay during diagenesis to illite. The elevated levels of iron and magnesium around the periphery of the specimens are thus coincident with, but formed later than, those for aluminium and silicon (the principal components of the clays).

\section{Later events}

Their incorporation into concretions ensured that the long term preservation potential of the fossils was enhanced. In contrast, fossils have yet to be recovered from the volcaniclastic ash.
This research was funded by NERC Grant GR9/03132 to Derek J. Siveter, D. E. G. Briggs and David J. Siveter. Assistance with funding was also provided by English Nature and a local quarrying company. Elemental mapping was partially supported by EU Large Scale Geochemical Facility Programme (Contract Number ERBFMGECT980128) at the Department of Earth Sciences, University of Bristol; S. Kearns provided invaluable assistance. We are grateful to R. J. Aldridge (Univ. Leicester) and two anonymous reviewers for valuable comments on the original manuscript, and to J. Hay (Univ. Oxford) for technical support. The Geological Society of London is thanked for defraying the expenses incurred by P.J.O. in attending the 1998 Lyell Meeting, at which this research was originally presented.

\section{References}

Aldridge, R.J., Briggs, D.E.G., Smith, M.P., Clarkson, E.N.K. \& Clark, N.D.L. 1993. The anatomy of conodonts. Philosophical Transactions of the Royal Society of London, B340, 405-421.

Allison, P.A. 1988. The role of anoxia in the decay and mineralization of proteinaceous macro-fossils. Paleobiology, 14, 139-154. 
— \& Briggs, D.E.G. 1991. The taphonomy of soft-bodied animals. In: Donovan, S.K. (ed.) The processes of fossilization. Belhaven Press, London, 120-140.

Baird, G.C., Sroka, S.D., Shabica, C.W. \& Beard, T.L. 1985. Mazon Creek-type fossil assemblages in the United States midcontinent Pennsylvanian: their recurrent character and paleoenvironmental significance. Philosophical Transactions of the Royal Society of London, B311, 87-99.

BERNER, R.A. 1968. Calcium carbonate concretions formed by the decomposition of organic matter. Science, 159, 195-197.

Briggs, D.E.G. \& Clarkson, E.N.K. 1989. Environmental controls on the taphonomy and distribution of Carboniferous malacostracan crustaceans. Transactions of the Royal Society of Edinburgh. Earth Sciences, 80, 293-301.

\& KeAR, A.J. 1993. Decay and preservation of polychaetes-taphonomic thresholds in soft-bodied organisms. Paleobiology, 19, 107-135.

- \& - 1994. Decay and mineralization of shrimps. Palaios, 9, 431-456.

- \& Nedin, C. 1997. The taphonomy and affinities of the problematic fossil Myoscolex from the Lower Cambrian Emu Bay Shale of South Australia. Journal of Paleontology, 71, 22-32.

- Clarkson, E.N.K. \& Aldridge, R.J. 1983. The conodont animal. Lethaia, 16, 1-14.

—, Siveter, D.J. \& Siveter, D.J. 1996. Soft-bodied fossils from a Silurian volcaniclastic deposit. Nature, 382, 248-250.

Chaftez, H.S. \& Buczynski, C. 1992. Bacterially induced lithification of microbial mats. Palaios, 7, 277-293.

Coleman, M.L. 1993. Microbial processes: Controls on the shape and composition of carbonate concretions. Marine Geology, 113, 127-140.

Conway Morris, S. 1986. The community structure of the Middle Cambrian Phyllopod Bed (Burgess Shale). Palaeontology, 29, 423-467.

Glaessner, M.F. 1979. Lower Cambrian Crustacea and annelid worms from Kangaroo Island, South Australia. Alcheringa, 3, 21-31.

GregG, J.M. \& Sibley, D.F. 1984. Epigenetic dolomitization and the origin of xenotopic dolomite texture. Journal of Sedimentary Petrology, 54, 908-931.

Holman, J.A., Harington, C.R. \& Mott, R.J. 1997. Skeleton of a leopard frog (Rana pipiens) from Champlain Sea deposits (ca. $10000 \mathrm{BP}$ ) near Eardley, Quebec. Canadian Journal of Earth Sciences, 34, 1150-1155.

Irwin, M., Coleman, M.L. \& CuRTis, C.D. 1977. Isotopic evidence for source of diagenetic carbonates formed during burial of organic-rich sediments. Nature, 269, 209-213.

JACKSON, K.S., JonASSON, I.R. \& SKIPPEN, G.B. 1978. The nature of metalssediment-water interactions in freshwater bodies, with emphasis on the role of organic matter. Earth Science Reviews, 14, 97-146.

Lagaly, G. 1984. Clay organic interactions. Philosophical Transactions of the Royal Society of London, A311, 315-332.

MartiLl, D.M. 1997. Fish oblique to bedding in early diagenetic concretions from the Cretaceous Santana Formation of Brazil-implications for substrate consistency. Palaeontology, 40, 1011-1026.

McAllister, D.E., Harington, C.R., Cumbaa, S.L. \& Renaud, C.B. 1988. Paleoenvironmental and biogeographic analyses of fossil fishes in
peri-Champlain Sea deposits in eastern Canada. In: GADD, N.R. (ed.) The late Quaternary development of the Champlain Sea basin. Geological Association of Canada Special Papers, 35, 241-258.

McHargue, T.R. \& Price, R.C. 1982. Dolomite from clay in argillaceous or shale-associated marine carbonates. Journal of Sedimentary Petrology, 52, 873-886.

Mortland, M.M. 1970. Clay-organic complexes and interactions. Advances in Agronomy, 22, 75-117.

MülLer, K.J. 1985. Exceptional preservation in calcareous nodules. Philosophical Transactions of the Royal Society of London, B311, 67-73.

ODom, I.E. 1984. Smectite clay-minerals-properties and uses. Philosophical Transactions of the Royal Society of London, A311, 391-409.

Palmer, A.R. 1957. Miocene arthropods from the Mojave Desert, California. US Geological Survey Professional Paper, 294-G, 237-280.

PARK, L.E. 1995. Geochemical and paleoenvironmental analysis of lacustrine arthropod-bearing concretions of the Barstow Formation, southern California. Palaios, 10, 44-57.

Schram, F.R., Vonk, R. \& HoF, C.H.J. 1997. Mazon Creek Cycloidea. Journal of Paleontology, 71, 261-284.

Shear, W.A. \& Kukalova-Peck, J. 1990. The ecology of Paleozoic terrestrial arthropods: the fossil evidence. Canadian Journal of Zoology, 68, 1807-1834.

Sibley, D.F. \& GregG, J.M. 1987. Classification of dolomite rock textures. Journal of Sedimentary Petrology, 57, 967-975.

Stankiewicz, B.A., Briggs, D.E.G. \& Evershed, R.P. 1997. Chemical composition of Paleozoic and Mesozoic fossil invertebrate cuticles as revealed by pyrolysis-gas chromatography/mass spectrometry. Energy and Fuels, 11, $515-521$.

Walcott, C.D. 1912. Middle Cambrian Branchiopoda, Malacostraca, Trilobita and Merostomata Cambrian Geology and Paleontology II. Smithsonian Miscellaneous Collections, 57, 145-228.

WALOSSEK, D. \& MüLLER, K.J. 1992. The Alum Shale window-contribution of Orsten arthropods to the phylogeny of Crustacea. Acta Zoologica, 73 305-312.

WiLBY, P.R. \& BRIGGS, D.E.G. 1997. Taxonomic trends in the resolution of detail preserved in fossil phosphatized soft tissues. Geobios. M.S., 20, 493-502.

— \& Whyte, M.A. 1995. Phosphatized soft tissues in bivalves from the Portland Roach of Dorset (Upper Jurassic). Geological Magazine, 132, 117-120.

, Briggs, D.E.G. \& Riou, B. 1996. Mineralization of soft-bodied invertebrates in a Jurassic metalliferous deposit. Geology, 24, 847-850.

Williams, A. \& Cusack, M. 1997. Lingulid shell mediation in clay formation. Lethaia, 29, 349-360.

WiLLs, M.A. 1998. Cambrian and Recent disparity: the picture from priapulids. Paleobiology, 24, 177-199.

—, Briggs, D.E.G. \& Fortey, R.A. 1994. Disparity as an evolutionary index - a comparison of Cambrian and Recent arthropods. Paleobiology, 20, $93-130$. 